Check for updates

Cite this: RSC Adv., 2018, 8, 14229

Received 18th January 2018

Accepted 26th March 2018

DOI: $10.1039 / c 8 r a 00536 b$

rsc.li/rsc-advances

\section{Candida rugosa lipase covalently immobilized on facilely-synthesized carbon nitride nanosheets as a novel biocatalyst $\uparrow$}

\author{
Ya Li,,$^{\mathrm{a}}$ Zhijun Ruan, $\mathbb{D} \dagger^{\mathrm{b}}$ Mingming Zheng, ${ }^{a}$ Qianchun Deng, ${ }^{\mathrm{a}}$ Shan Zhang, ${ }^{\mathrm{a}}$ \\ Chang Zheng, ${ }^{a}$ Hu Tang, (D) ${ }^{a}$ Fenghong Huang ${ }^{\star a}$ and Jie Shi (DD *a
}

\begin{abstract}
The immobilization of lipase on solid supports provides a significant improvement to the stability and reusability of lipase. During immobilization, the restricted surface area and inferior separation capacity of matrix materials are crucial for obtaining high-quality immobilized lipase. Carbon nitride nanosheets $\left(\mathrm{C}_{3} \mathrm{~N}_{4}\right.$-NS) as a type of two-dimensional nanomaterial have attracted various attentions for their prominent 2D planar nanostructure, characteristic surface area, thermostability and biocompatibility. Herein, we report a rational design and fabrication of immobilized Candida rugosa lipase based on carbon nitride nanosheets $\left(\mathrm{C}_{3} \mathrm{~N}_{4}-\mathrm{NS}\right)$ as the matrix. The synthetic $\mathrm{C}_{3} \mathrm{~N}_{4}-\mathrm{NS}$ are characterized by transmission electron microscopy, Brunauer-Emmett-Teller gas sorptometry measurement, $\mathrm{X}$-ray powder diffraction, Fourier transform infrared spectroscopy and thermogravimetric analysis. These results show that $\mathrm{C}_{3} \mathrm{~N}_{4}$-NS possess an as-expected two-dimensional nanostructure with a large surface area of $74.374 \mathrm{~m}^{2} \mathrm{~g}^{-1}$. In addition, we chose glutaraldehyde-assisted covalent attachment to combine $\mathrm{C}_{3} \mathrm{~N}_{4}$-NS and Candida rugosa lipase (CRL) via amino groups at the margins of $\mathrm{C}_{3} \mathrm{~N}_{4}-\mathrm{NS}$. The asconstructed immobilized lipase $\left(\mathrm{C}_{3} \mathrm{~N}_{4}-\mathrm{NS} @ \mathrm{CRL}\right)$ exhibits satisfactory enzyme-loading $\left(44.76 \mathrm{mg} \mathrm{g}^{-1}\right)$, $\mathrm{pH}$-flexibility, thermostability (after $180 \mathrm{~min}$ at $50{ }^{\circ} \mathrm{C}, 67 \%$ of the initial activity remained) and recyclability (after 10 runs, $72 \%$ of the initial activity remained). When compared with the free CRL, all experimental data indicate that $\mathrm{C}_{3} \mathrm{~N}_{4}-\mathrm{NS}$ CCRL exhibited improved stability and enhanced practicability. To our knowledge, this is the first report of the application of carbon nitride nanosheets to enzyme immobilization.
\end{abstract}

\section{Introduction}

Due to their mild catalytic conditions, high catalytic efficiency, wide substrate specificity and fewer side effects in contrast with chemical catalysts, enzymes have rapidly attracted increasing attention from researchers and have been generally applied in extensive areas such as biocatalysis, pharmaceuticals, environmental protection, the food industry and biosensors. ${ }^{1}$ Noticeably, lipase (triacylglycerol ester hydrolase, E.C. 3.1.1.3), as a major player in the area of enzymes, is remarkably excellent in

\footnotetext{
${ }^{a}$ Hubei Key Laboratory of Lipid Chemistry and Nutrition, Oil Crops and Lipids Process Technology National \& Local Joint Engineering Laboratory, Key Laboratory of Oilseeds Processing, Ministry of Agriculture, Oil Crops Research Institute, Chinese Academy of Agricultural Sciences, Wuhan 430062, China. E-mail: shijie@caas.cn

${ }^{b}$ Hubei Key Laboratory of Processing and Application of Catalytic Materials, College of Chemistry and Chemical Engineering, Huanggang Normal University, Huanggang 438000, China

$\dagger$ Electronic supplementary information (ESI) available: Kinetic parameters for the free CRL and $\mathrm{C}_{3} \mathrm{~N}_{4}$-NS@CRL, effect of different organic solvents on the relative activity of the $\mathrm{C}_{3} \mathrm{~N}_{4}$-NS@CRL, fluorescence intensity of the fluorescamine method plotted as a function of increasing amounts of amino groups of fresh APTES. See DOI: 10.1039/c8ra00536b

$\$$ These authors equally contributed to this study.
}

the versatile reactions it catalyses, such as hydrolysis, esterification, transesterification, alcoholysis, ammolysis and $\mathrm{C}-\mathrm{C}$ bond formation. ${ }^{2}$ However, taking commercial utility into consideration, free lipase suffers from problems of low operational stability, difficult reusability and high cost. $^{3}$ Immobilization of lipase on suitable matrix materials via physical adsorption or covalent attachment has led it to show superior performance in enzyme activity, acid-base resistance properties, thermostability and recyclability when compared to the free form of lipase and provided glorious new trains of thought to break through these intractable dilemmas. Aimed at obtaining greater usefulness and better acclimation, appropriate supporting materials are becoming crucial to the immobilization of lipase. Although many sorts of carrier materials ranging from inorganics ${ }^{4}$ to organics $^{5}$ have been applied to immobilized lipase, outstanding strategies to design and fabricate immobilized lipase with high activity and stability are still in urgent demand.

Two-dimensional nanomaterials have offered great promise in the area of immobilized enzymes as carrier materials due to their unique nanostructure and attractive properties. It is clear to see that 2D nanomaterials could provide a large surface area to capture plentiful amounts of protein, with controllable 
surface functionalization to match multiple immobilization methods and a 2D nanostructure to guarantee enough space for mass transfer during catalytic processes. ${ }^{6}$ In recent years, graphene and graphene oxide (GO), shining stars in the $2 \mathrm{D}$ family, have exhibited outstanding performances as carrier materials and have been used to build various novel biocatalysts. ${ }^{7-9}$ However, there still exist several stumbling blocks to the use of graphene and GO, such as their complex, tedious and timeconsuming synthesis processes, and their high cost as commercial products, and these impose restrictions on the actual application value of immobilized enzymes based on them.

Recently, carbon nitride $\left(\mathrm{C}_{3} \mathrm{~N}_{4}\right)$, a two-dimensional layered structure, as a new type of metal-free conjugated semiconductor, has attracted a great deal of attention and has been widely applied in the field of photocatalysis research..$^{10}$ Compared with bulk samples, carbon nitride nanosheets $\left(\mathrm{C}_{3} \mathrm{~N}_{4}{ }^{-}\right.$ NS), the 2D nanostructure of carbon nitride with fewer layers, possess a better 2D planar microstructure, higher surface area and abundance of active sites, which reveals huge potential as a promising anchored material in the area of enzymes. ${ }^{11}$ Firstly, the $2 \mathrm{D}$ nanostructure of $\mathrm{C}_{3} \mathrm{~N}_{4}$-NS could ensure efficient mass transfer during the biocatalysis process, while the surface area of $\mathrm{C}_{3} \mathrm{~N}_{4}$-NS may assure adequate enzyme loading in the same way as other $2 \mathrm{D}$ nanomaterials. ${ }^{12}$ Secondly, numerous active chemical sites are exposed to the surface of $\mathrm{C}_{3} \mathrm{~N}_{4}-\mathrm{NS}^{13}$ The amino groups at the margins of the nanosheets are conducive to forming more stable biocatalysts via a covalent attachment procedure with the enzyme, accompanied by improved recovery efficiency. In addition, the synthesis processes of $\mathrm{C}_{3} \mathrm{~N}_{4}$-NS are simple, and it is easy to achieve large-scale production. The nitrogen-rich precursors chosen to fabricate the $\mathrm{C}_{3} \mathrm{~N}_{4}$-NS are cheap and available, for example cyanamide, dicyandiamide, melamine and urea. ${ }^{10}$ In the light of practical applications, $\mathrm{C}_{3} \mathrm{~N}_{4}$-NS seem to be more competitive for low cost. Besides, $\mathrm{C}_{3} \mathrm{~N}_{4}$-NS have been shown to have favorable biocompatibility, thermostability, chemical resistance stability and environmental friendliness in a series of literature reports. ${ }^{14}$ Hence, $\mathrm{C}_{3} \mathrm{~N}_{4}$-NS could work in harmony with various kinds of enzyme when extended to the area of immobilized enzymes. Shen et al. ${ }^{15}$ first selected mesoporous carbon nitride as the anchored material, realized the immobilization of Candida rugosa lipase via physical absorption and obtained an improved thermal stability of free CRL. However, after their research, related literature has rarely been reported continuously on immobilized enzymes based on $\mathrm{C}_{3} \mathrm{~N}_{4}$, in particular $\mathrm{C}_{3} \mathrm{~N}_{4}-\mathrm{NS}$.

Herein, we designed and facilely manufactured carbon nitride nanosheets $\left(\mathrm{C}_{3} \mathrm{~N}_{4}\right.$-NS) with a satisfactory $2 \mathrm{D}$ plane nanostructure and abundant residual amino groups as a novel anchored material. We selected Candida rugosa lipase (CRL) as the proof-of-concept model and assessed the potential applicability of $\mathrm{C}_{3} \mathrm{~N}_{4}$-NS as an anchored material in immobilized lipase. On one hand, the $2 \mathrm{D}$ plane nanostructure of $\mathrm{C}_{3} \mathrm{~N}_{4}-\mathrm{NS}$ guarantees enzymatic reactions operating in a sufficient space and accelerates mass transfer efficiency. On the other hand, abundant residual amino groups make it easy to adopt a chemical cross-linking approach to bond the enzyme and anchored matrix together, offering a stable configuration and avoiding the leaching of the enzyme. The whole rationale design is briefly illustrated in Scheme 1 and explained as follows. Large-scale carbon nitride nanosheets were successfully prepared via a top-down approach with dicyanodiamine as the nitrogen-rich precursor under a high-temperature calcination process. In addition, Candida rugosa lipase (CRL) was firmly immobilized on carbon nitride nanosheets via covalent attachments assisted by glutaraldehyde molecules. Experimental results indicated that the resultant immobilized lipase $\left(\mathrm{C}_{3} \mathrm{~N}_{4}\right.$-NS@CRL) revealed an enhanced enzyme-loading (44.76 $\mathrm{mg} \mathrm{g}^{-1}$ ), pH-flexibility ( $\mathrm{pH} 4.0-8.0$ ), thermostability $\left(180 \mathrm{~min}\right.$ at $50{ }^{\circ} \mathrm{C}$ ) and recyclability (after 10 runs, $72 \%$ of the initial activity remained). Consequently, our work could not only prove that $\mathrm{C}_{3} \mathrm{~N}_{4}$-NS is an effective carrier for immobilized lipase, but also may provide a new method to construct biocatalysts with improved catalytic efficiency and convenient reuse. To the best of our knowledge, this paper is the first report of the application of 2D-nanostructured carbon nitride nanosheets in the area of immobilized enzymes.

\section{Materials and methods}

\subsection{Materials}

Dicyandiamide (DCDA, 99\%), $p$-nitrophenylpalmitate ( $p$-NPP, Aldrich, 99\%), and Candida rugosa lipase (CRL, lyophilized powder, Type VII, $700 \mathrm{U}$ per $\mathrm{mg}$ solid) were purchased from Sigma-Aldrich (St. Louis, USA). Absolute ethanol (EtOH), glutaraldehyde solution (25\%), disodium hydrogen phosphate dodecahydrate $\left(\mathrm{Na}_{2} \mathrm{HPO}_{4} \cdot 12 \mathrm{H}_{2} \mathrm{O}\right)$, and sodium dihydrogen phosphate dihydrate $\left(\mathrm{NaH}_{2} \mathrm{PO}_{4} \cdot 2 \mathrm{H}_{2} \mathrm{O}\right)$ were supplied by

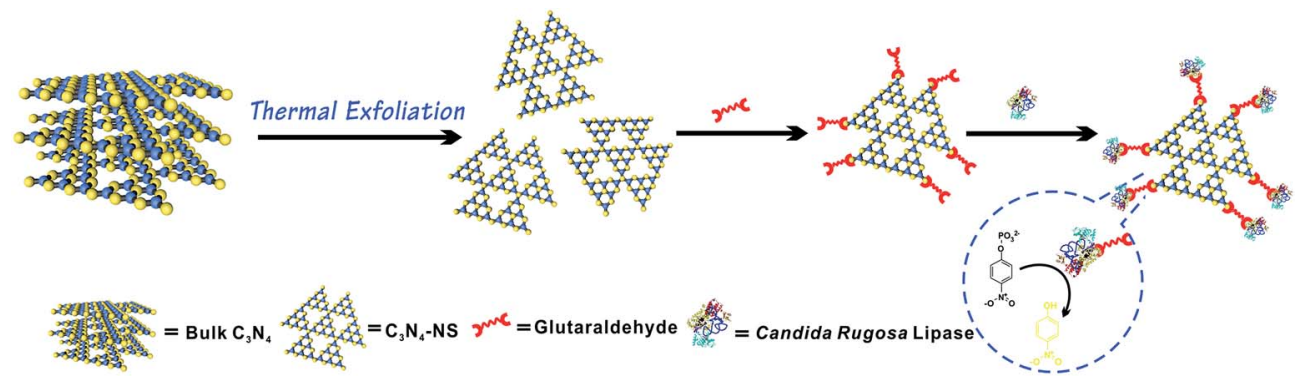

Scheme 1 Schematic representation of the formation of $\mathrm{C}_{3} \mathrm{~N}_{4}-\mathrm{NS} \cap C R L$. 
Sinopharm Chemical Reagent Co., Ltd (Shanghai, China). An Enhanced (BCA) Protein Assay Kit was obtained from Shanghai Labaide Biotechnology Co., Ltd (Shanghai, China). Ultrapure water was obtained with Milli-Q apparatus (Millipore, Bedford, MA, USA). All chemicals were of analytical reagent grade and used as received without any further purification.

\subsection{Characterization}

The morphologies of obtained samples were characterized using a transmission electron microscope (Tecnai G2 F30, FEI, USA) operated on $300 \mathrm{kV}$. The crystal phases of samples were measured using a Bruker D8 Advance X-ray diffractometer (Bruker, Germany) with a $2 \theta$ range from $10^{\circ}$ to $80^{\circ}$ with $\mathrm{Cu} \mathrm{K} \alpha$ irradiation. The nitrogen sorption isotherms were measured with an Autosorb-iQ2 (Quantachrome, USA) analyzer. X-ray photoelectron spectroscopy (XPS) analysis was conducted with a Quantera II (ULVAC-PHI, Japan) X-ray photoelectron spectrometer equipped with an $\mathrm{Al} \mathrm{K} \alpha \mathrm{X}$-ray radiation source. FT-IR spectra were characterized on a Bruker Tensor 27 FT-IR spectrometer (Thermoelectron, USA) with the $\mathrm{KBr}$ pellet technique. The thermal stabilities of $\mathrm{C}_{3} \mathrm{~N}_{4}$-NS and $\mathrm{C}_{3} \mathrm{~N}_{4}$-NS@CRL were studied with a thermogravimetric (TGA) analyzer (TAQ50, Netzsch, Germany) at a heating rate of $5{ }^{\circ} \mathrm{C} \min ^{-1}$ in a $\mathrm{N}_{2}$ atmosphere. The UV-vis absorption spectra were recorded using a DU 800 UV-vis spectrometer (Beckman Coulter, Japan).

\subsection{Preparation of graphitic carbon nitride nanosheets $\left(\mathrm{C}_{3} \mathbf{N}_{\mathbf{4}}\right.$-NS)}

Graphitic carbon nitride nanosheets $\left(\mathrm{C}_{3} \mathrm{~N}_{4}-\mathrm{NS}\right)$ were prepared with reference to literature methods with moderate modifications. ${ }^{16}$ Dicyandiamide $(6 \mathrm{~g})$ was placed into an alumina crucible $(50 \mathrm{~mL})$ with a lid, then transferred into a tube furnace, heated at a rate of $2.3{ }^{\circ} \mathrm{C} \min ^{-1}$ up to $550{ }^{\circ} \mathrm{C}$ and held at $550{ }^{\circ} \mathrm{C}$ for $4 \mathrm{~h}$ in a $\mathrm{N}_{2}$ atmosphere before being cooled down naturally. Then the yellow solid in the alumina crucible was collected and ground into a powder with an agate mortar. Next, the obtained yellow powder was placed into a porcelain crucible $(50 \mathrm{~mL})$, heated at a rate of $5{ }^{\circ} \mathrm{C} \min ^{-1}$ up to $500{ }^{\circ} \mathrm{C}$ and maintained at this temperature for $2 \mathrm{~h}$ in a $\mathrm{N}_{2}$ atmosphere before being cooled down naturally in the tube furnace. The finally-obtained pale yellow powder was graphitic carbon nitride nanosheets $\left(\mathrm{C}_{3} \mathrm{~N}_{4}\right.$ NS).

\subsection{Immobilization of Candida rugosa lipase on $\mathrm{C}_{3} \mathrm{~N}_{4}-\mathrm{NS}$ $\left(\mathrm{C}_{3} \mathrm{~N}_{4}\right.$-NS@CRL)}

The immobilization of Candida rugosa lipase (CRL) on $\mathrm{C}_{3} \mathrm{~N}_{4}-\mathrm{NS}$ was performed by the cross-linking method assisted by glutaraldehyde according to literature reports. ${ }^{17} 79 \mathrm{~mL}$ PBS buffer (0.1 M, pH 7.0) and $25 \mathrm{~mL}$ of glutaraldehyde solution $(25 \%, \mathrm{w} / \mathrm{v})$ were successively added to $3.22 \mathrm{~g} \mathrm{C}_{3} \mathrm{~N}_{4}$-NS in a $250 \mathrm{~mL}$ Erlenmeyer flask with sonication treatment. Then, the mixture was incubated at $65{ }^{\circ} \mathrm{C}$ in a shaker operating at $160 \mathrm{rpm}$ for $12 \mathrm{~h}$. Subsequently, the activated carrier was separated and repeatedly washed with distilled water 3 times via vacuum filtration. Finally, the product was dried in a vacuum oven at $25{ }^{\circ} \mathrm{C}$ overnight, and the material was named $\mathrm{G}-\mathrm{C}_{3} \mathrm{~N}_{4}-\mathrm{NS}$.
$4 \mathrm{~g}$ CRL was fully dissolved in $200 \mathrm{~mL} \mathrm{0.1} \mathrm{M} \mathrm{PBS} \mathrm{(pH} \mathrm{7.0)} \mathrm{with}$ mild shaking at $37^{\circ} \mathrm{C}$. After the obtained CRL solution was centrifuged, the supernatant was collected and retained. The obtained $\mathrm{G}-\mathrm{C}_{3} \mathrm{~N}_{4}$-NS was dispersed in the lipase solution, and then incubated at $37{ }^{\circ} \mathrm{C}$ in a shaker operating at $160 \mathrm{rpm}$ for $12 \mathrm{~h}$. The immobilized lipase $\left(\mathrm{C}_{3} \mathrm{~N}_{4}-\mathrm{NS} @ \mathrm{CRL}\right)$ was collected by refrigerated centrifugation, washed with $0.1 \mathrm{M}$ PBS ( $\mathrm{pH} 7.0) 3$ times, freeze-dried overnight and stored in a refrigerator at $4{ }^{\circ} \mathrm{C}$. The influences of initial concentration of the CRL solution on the efficiency of protein loading were explored by bringing carriers $\left(30 \mathrm{mg}\right.$ ) into contact with $1-20 \mathrm{mg} \mathrm{mL}^{-1}$ of CRL solutions with different initial concentrations at a fixed temperature of $37^{\circ} \mathrm{C}$ and $0.1 \mathrm{M} \mathrm{pH} \mathrm{7.0} \mathrm{PBS} \mathrm{for} 6 \mathrm{~h}$.

The protein concentration of $\mathrm{C}_{3} \mathrm{~N}_{4}$-NS@CRL was determined by the Bradford method, using bovine serum albumin as a standard. ${ }^{18}$ The amount of immobilized lipase was calculated by detecting the amount of un-immobilized lipase. Calculated from the experimental results, the free CRL solution contained $0.062 \mathrm{mg}$ of protein per $\mathrm{mL}$.

\subsection{Enzymatic activity assay}

The activities of the free and immobilized lipases were measured by the hydrolysis of $p$-NPP in a buffer solution at $37^{\circ} \mathrm{C}$ for $5 \mathrm{~min}$ at $160 \mathrm{rpm}$. The concentration of the hydrolysis product $p$-nitrophenol ( $p$-NP) was measured using a spectrophotometric method on an ultraviolet-visible spectrophotometer and the value of absorbance at $410 \mathrm{~nm}$ was collected. $30 \mathrm{mg}$ of immobilized lipase (or $100 \mathrm{mg}$ of free lipase) was added to a tube that contained $1 \mathrm{~mL}$ of $0.5 \% p$-nitrophenylpalmitate ethanol solution (w/v) and $1 \mathrm{~mL}$ of $0.1 \mathrm{M}$ PBS ( $\mathrm{pH} 7.0)$, then incubated at $160 \mathrm{rpm}$ at $37{ }^{\circ} \mathrm{C}$ for $5 \mathrm{~min}$. The reaction was terminated by adding $2 \mathrm{~mL}$ of $25 \mathrm{~g} \mathrm{~L}^{-1} \mathrm{Na}_{2} \mathrm{CO}_{3}$ solution. After refrigerated centrifuging at $5000 \mathrm{rpm}$ for $10 \mathrm{~min}, 1 \mathrm{~mL}$ of the supernatant was taken and diluted with distilled water, then the value of absorbance at $410 \mathrm{~nm}$ was detected on an ultravioletvisible spectrophotometer. The molar absorption coefficient $\left(\varepsilon=410 \mathrm{~nm}\right.$ ) was $14519 \mathrm{M}^{-1} \mathrm{~cm}^{-1}$ under the same conditions as above according to the Beer-Lambert law. One unit of activity (U) was defined as the amount of enzyme that hydrolyzes $1 \mu \mathrm{mol}$ of $p$-nitrophenylpalmitate per minute under the conditions described previously.

The activities obtained from other conditions were defined as relative activities, and we assumed the maximum activity value of the immobilized and free lipase under optimal conditions to be $100 \%$. The effect of temperature on the activities of free and immobilized lipases was investigated at $\mathrm{pH} 7.0$ at different temperatures $\left(30,40,50,60,70\right.$, and $\left.80^{\circ} \mathrm{C}\right)$ for $1 \mathrm{~h}$. The effect of $\mathrm{pH}$ on the activities of free and immobilized lipases was investigated at $37^{\circ} \mathrm{C}$ under a variety of $\mathrm{pHs}(3.0,4.0,5.0,6.0,7.0$, and 8.0) for $1 \mathrm{~h}$. Each treatment was repeated three times.

\subsection{Thermal stability of $\mathrm{C}_{3} \mathbf{N}_{4}$-NS@CRL}

The thermal stability of the immobilized lipase was studied by incubating the biocatalyst in $0.1 \mathrm{M}$ PBS ( $\mathrm{pH} 7.0$ ) from 0 min to $180 \mathrm{~min}$ at $50{ }^{\circ} \mathrm{C}$. Periodically, samples were withdrawn every $30 \mathrm{~min}$, and their residual activities were assayed by the 
hydrolysis of $p$-NPP as described above. Residual activity was expressed as a percentage of initial activity (hydrolytic activity before thermal incubation).

\subsection{Reusability of $\mathrm{C}_{3} \mathrm{~N}_{4}-\mathrm{NS}$ @CRL}

The reusability of the immobilized lipase was determined by the following procedure: $30 \mathrm{mg}$ of immobilized lipase was used for the hydrolysis of $p$-NPP ethanol solution in $0.1 \mathrm{M} \mathrm{pH} 7.0$ phosphate buffer for $5 \mathrm{~min}$ at $37{ }^{\circ} \mathrm{C}$ under mild stirring. After each batch reaction, the immobilized lipase was collected by refrigerated centrifugation, washed three times with absolute ethanol, dried with a nitrogen purge and reused for the next cycle. The lipase activity was calculated as in the above description.

\section{Results and discussions}

\subsection{Characterization}

In order to prove that the designed immobilization was performed successfully, we investigated the morphologies of $\mathrm{C}_{3} \mathrm{~N}_{4}$ NS and $\mathrm{C}_{3} \mathrm{~N}_{4}$-NS@CRL by transmission electron microscopy (TEM). Generally, the bulk $\mathrm{C}_{3} \mathrm{~N}_{4}$ showed a layered structure with dicyandiamide as the precursor via a thermal condensation process. After the thermal exfoliation step, we obtained the $2 \mathrm{D}$ planar graphene-like carbon nitride nanosheets $\left(\mathrm{C}_{3} \mathrm{~N}_{4}-\mathrm{NS}\right)$, which exhibited silk-like plicated slices with a micron-scale planar size as seen in the TEM image (Fig. 1A). After immobilization of Candida rugosa lipase on $\mathrm{C}_{3} \mathrm{~N}_{4}$-NS assisted by a crosslinking agent, the silk-like $\mathrm{C}_{3} \mathrm{~N}_{4}$-NS surface appeared to contain some blocky materials as shown in Fig. 1B, which were considered to be the agglomerate shape of CRL consistent with previous reports, and proved that $\mathrm{CRL}$ was bonded with $\mathrm{C}_{3} \mathrm{~N}_{4^{-}}$ NS. ${ }^{9}$ This point could be confirmed by the nitrogen adsorptiondesorption isotherm observations of $\mathrm{C}_{3} \mathrm{~N}_{4}$-NS and $\mathrm{C}_{3} \mathrm{~N}_{4}$ NS@CRL in Fig. 1C. According to the IUPAC classification, both of the two adsorption isotherms were not reversible and were mainly attributed to a type IV isotherm with hysteresis loops. The $\mathrm{C}_{3} \mathrm{~N}_{4}$-NS displayed a large BET surface area of $74.4 \mathrm{~m}^{2} \mathrm{~g}^{-1}$; while after immobilization of free CRL, the BET surface area of $\mathrm{C}_{3} \mathrm{~N}_{4}$-NS@CRL was only $19.6 \mathrm{~m}^{2} \mathrm{~g}^{-1}$. The decrease in the surface area of $\mathrm{C}_{3} \mathrm{~N}_{4}$-NS@CRL compared to the parent $\mathrm{C}_{3} \mathrm{~N}_{4}$-NS was due to the blockage of carbon nitride nanosheets with CRL lipase after immobilization. In addition, we examined the critical lattice structures of all of the prepared nanomaterials during the immobilization process using X-ray diffraction (XRD). As shown in Fig. 1D, all of the four samples revealed two similar characteristic diffraction angles at $13^{\circ}$ and $27^{\circ}$. The small peak $\left(2 \theta=13^{\circ}\right)$ was attributed to the $(100)$ in-plane repeat units of tri-s-triazine. Meanwhile, the later dominant peak $(2 \theta=$ $27^{\circ}$ ) originated from the (002) interlayer diffraction of graphitelike layered structures. ${ }^{19}$ The slight weakening of the characteristic peaks of $\mathrm{C}_{3} \mathrm{~N}_{4}$-NS compared to the $\mathrm{C}_{3} \mathrm{~N}_{4}$ samples
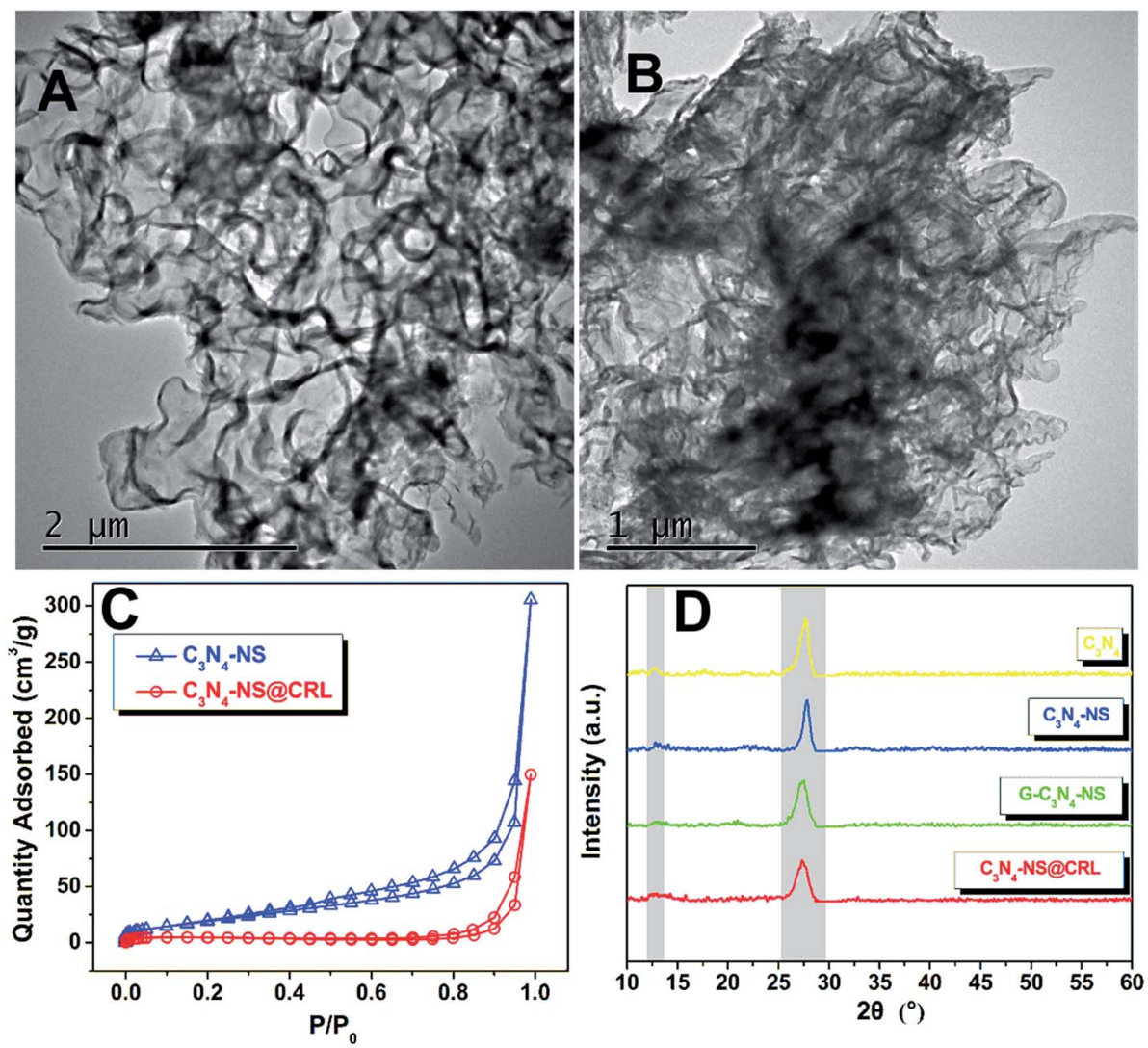

Fig. 1 TEM images of $\mathrm{C}_{3} \mathrm{~N}_{4}-\mathrm{NS}$ (A) and $\mathrm{C}_{3} \mathrm{~N}_{4}-\mathrm{NS} @ \mathrm{CRL}$ (B); (C) nitrogen adsorption-desorption isotherms of $\mathrm{C}_{3} \mathrm{~N}_{4}-\mathrm{NS}$ and $\mathrm{C}_{3} \mathrm{~N}_{4}-\mathrm{NS}$ @CRL; (D) the powder XRD patterns of $\mathrm{C}_{3} \mathrm{~N}_{4}, \mathrm{C}_{3} \mathrm{~N}_{4}-\mathrm{NS}, \mathrm{G}-\mathrm{C}_{3} \mathrm{~N}_{4}-\mathrm{NS}$ and $\mathrm{C}_{3} \mathrm{~N}_{4}-\mathrm{NS} @ \mathrm{CRL}$. 
suggested that the interlayer stacking pattern of $\mathrm{C}_{3} \mathrm{~N}_{4}$ and the planar size of $\mathrm{C}_{3} \mathrm{~N}_{4}$ layers were weakened during the exfoliation process. Meanwhile, the characteristic diffraction angles of glutaraldehyde-modified $\mathrm{C}_{3} \mathrm{~N}_{4}$-NS $\left(\mathrm{G}^{-} \mathrm{C}_{3} \mathrm{~N}_{4}-\mathrm{NS}\right)$ and $\mathrm{C}_{3} \mathrm{~N}_{4}$ NS@CRL exhibited no obvious difference to $\mathrm{C}_{3} \mathrm{~N}_{4}-\mathrm{NS}$, indicating that $\mathrm{C}_{3} \mathrm{~N}_{4}$-NS retained its specific crystal texture and could ensure the mass transfer on the surface of $\mathrm{C}_{3} \mathrm{~N}_{4}$-NS@CRL during catalytic reactions.

In addition, we figured out another clue by X-ray photoelectron spectroscopy (XPS) to verify the existence of covalent bonding via checking the surface compositions and the valence states of those obtained samples. According to the survey XPS spectra, all of the obtained samples contained C 1s $(287 \mathrm{eV}), \mathrm{N}$ 1s (397 eV) and $\mathrm{O} 1 \mathrm{~s}(531 \mathrm{eV})$ elements (Fig. 2A). The amount of oxygen in $\mathrm{C}_{3} \mathrm{~N}_{4}$-NS, glutaraldehyde-modified $\mathrm{C}_{3} \mathrm{~N}_{4}$-NS $\left(\mathrm{G}^{-} \mathrm{C}_{3} \mathrm{~N}_{4}\right.$ NS) and $\mathrm{C}_{3} \mathrm{~N}_{4}$-NS@CRL was 3.4\%, 2.1\% and 15.3\%, respectively. The negligible $\mathrm{O} 1 \mathrm{~s}$ peaks of $\mathrm{C}_{3} \mathrm{~N}_{4}$-NS and $\mathrm{G}-\mathrm{C}_{3} \mathrm{~N}_{4}-\mathrm{NS}$ could be ascribed to the tiny amount of $\mathrm{O}_{2}$ adsorbed on the surface of the two products. Nevertheless, due to the CRL containing more oxygen and $\mathrm{O}_{2}$ adsorbed on the surface of $\mathrm{C}_{3} \mathrm{~N}_{4}-\mathrm{NS}$, the $\mathrm{O} 1 \mathrm{~s}$ peak at $531 \mathrm{eV}$ of $\mathrm{C}_{3} \mathrm{~N}_{4}$-NS@CRL became much stronger, which could also illustrate that CRL was favourably anchored to the surface of $\mathrm{C}_{3} \mathrm{~N}_{4}$-NS. All of the high-resolution $\mathrm{N}$ 1s spectra of the $\mathrm{C}_{3} \mathrm{~N}_{4}$-NS could be deconvoluted into two peaks (Fig. 2B). The main peak at $397.3 \mathrm{eV}$ corresponded to $\mathrm{sp}^{2}$ hybridized $\mathrm{N}$ atoms bonded with carbon atoms $(\mathrm{C}=\mathrm{N}-\mathrm{C})$ in tri-s-triazine rings. The peak at $399.1 \mathrm{eV}$ was attributed to the bridging $\mathrm{N}$ atoms bonded to $\mathrm{C}$ atoms in the form of amino groups $\left((\mathrm{C})_{2}-\mathrm{NH}\right)$ connected with structural defects or $\mathrm{N}-(\mathrm{C})_{3}$ groups in the aromatic cycles. ${ }^{19}$
The above results indicated that $\mathrm{C}_{3} \mathrm{~N}_{4}$-NS consisted of the heptazine heterocyclic ring unit. As we expected, for $\mathrm{C}_{3} \mathrm{~N}_{4}-\mathrm{NS}$ modified by glutaraldehyde or equipped with CRL, the $399.1 \mathrm{eV}$ peak in $\mathrm{C}_{3} \mathrm{~N}_{4}$-NS was slightly shifted to weaker bonding energy regions, $398.8 \mathrm{eV}$ in $\mathrm{G}_{-} \mathrm{C}_{3} \mathrm{~N}_{4}-\mathrm{NS}$ and $398.6 \mathrm{eV}$ in $\mathrm{C}_{3} \mathrm{~N}_{4}-\mathrm{NS} @ \mathrm{CRL}$, which could be attributed to the amide bonds (-CO-NH-) generated from the cross-linking procedures. It could be found that $\mathrm{C} 1 \mathrm{~s}$ of $\mathrm{C}_{3} \mathrm{~N}_{4}$-NS could be separated into two peaks at 283.6 and $286.8 \mathrm{eV}$, indicating two types of carbon bonding in the $\mathrm{C}_{3} \mathrm{~N}_{4}$-NS (Fig. 2C). Among them, the binding energy peak at $283.6 \mathrm{eV}$ was ascribed to characteristic $\mathrm{sp}^{2} \mathrm{C}-\mathrm{C}$ and $\mathrm{N}-\mathrm{C}=\mathrm{N}$ bonds, and the binding energy peak at $286.8 \mathrm{eV}$ was attributed to $\mathrm{C}-\mathrm{OR}$ and $\mathrm{O}-\mathrm{C}=\mathrm{O}$ bonds. ${ }^{19}$ After $\mathrm{C}_{3} \mathrm{~N}_{4}$-NS was modified by glutaraldehyde or equipped with CRL, a new peak at $285 \mathrm{eV}$ appeared, which could be attributed to $\mathrm{sp}^{2} \mathrm{C}=\mathrm{O}$ bonds in the aldehyde group of glutaraldehyde in $\mathrm{G}^{-} \mathrm{C}_{3} \mathrm{~N}_{4}$-NS and amide bonds in $\mathrm{C}_{3} \mathrm{~N}_{4}$-NS@CRL. All of the results from the highresolution XPS analysis demonstrated that CRL was successfully linked to $\mathrm{C}_{3} \mathrm{~N}_{4}$-NS through a covalent method.

The FT-IR spectra of $\mathrm{C}_{3} \mathrm{~N}_{4}-\mathrm{NS} @ C R L, C R L, \mathrm{G}_{3} \mathrm{C}_{4}-\mathrm{NS}$ and $\mathrm{C}_{3} \mathrm{~N}_{4}$-NS were shown in Fig. 3A. $\mathrm{C}_{3} \mathrm{~N}_{4}-\mathrm{NS}, \mathrm{G}-\mathrm{C}_{3} \mathrm{~N}_{4}-\mathrm{NS}$ and $\mathrm{C}_{3} \mathrm{~N}_{4}$ NS@CRL displayed the similar characteristic absorption bands of $\mathrm{C}_{3} \mathrm{~N}_{4}$ networks. The broad peaks between 3600 and $3000 \mathrm{~cm}^{-1}$ were attributed to $-\mathrm{NH}_{2}$ stretching of the aromatic ring. Meanwhile, the bands of 1635, 1574, 1545, 1462 and $1402 \mathrm{~cm}^{-1}$ were assigned to characteristic stretching vibrations of the tri-s-triazine derived repeating units. The peaks at 1319 and $1244 \mathrm{~cm}^{-1}$ corresponded to stretching vibrations of aromatic C-N connected units of $\mathrm{N}-(\mathrm{C})_{3}, \mathrm{C}-\mathrm{NH}-\mathrm{C}$ or $\mathrm{C}-\mathrm{NH}_{2}$.

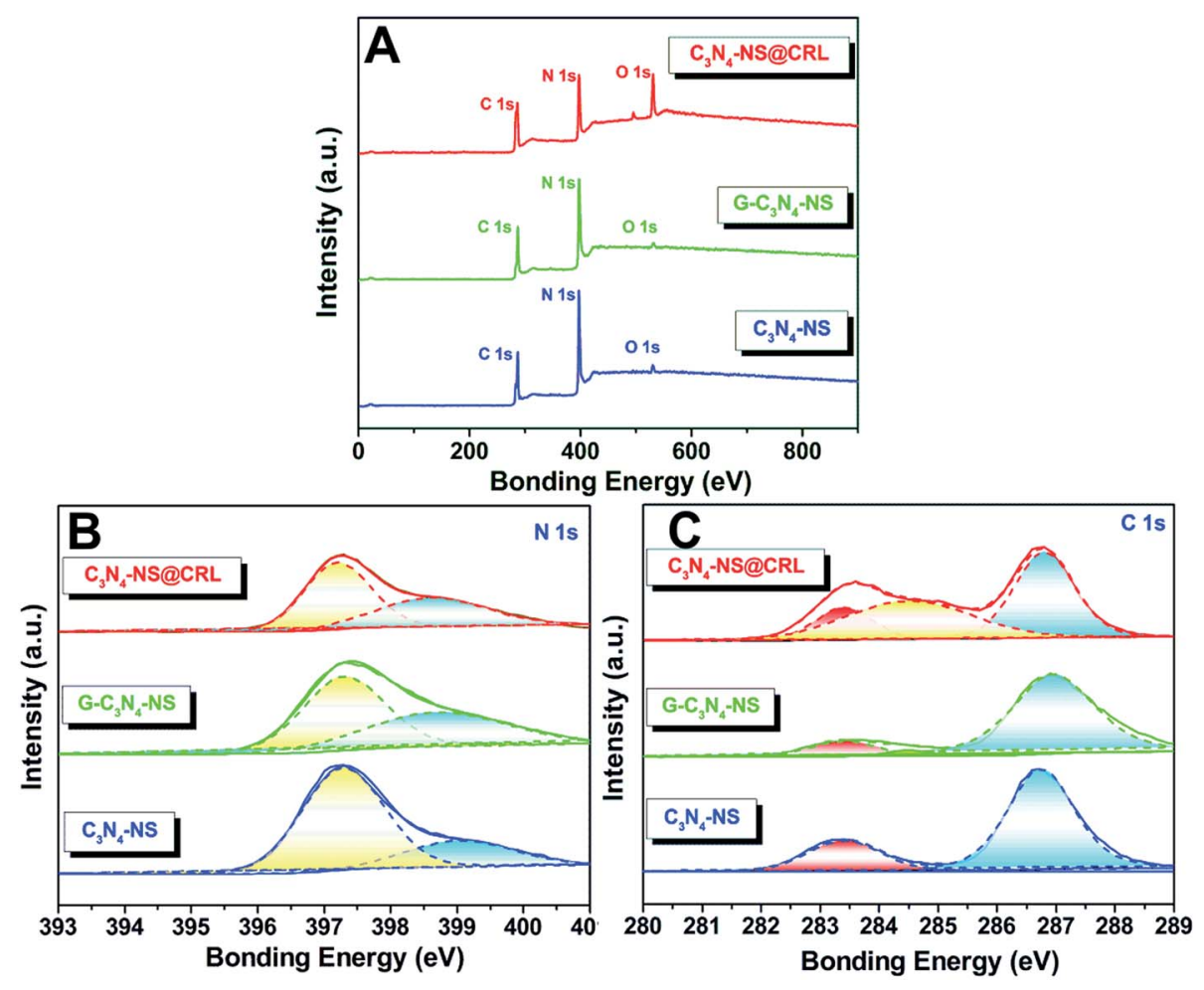

Fig. 2 XPS spectra (A), high-resolution $N$ 1s (B) and high-resolution $C$ 1s (C) of $C_{3} N_{4}-N S @ C R L, G-C_{3} N_{4}-N S$ and $C_{3} N_{4}-N S$. 

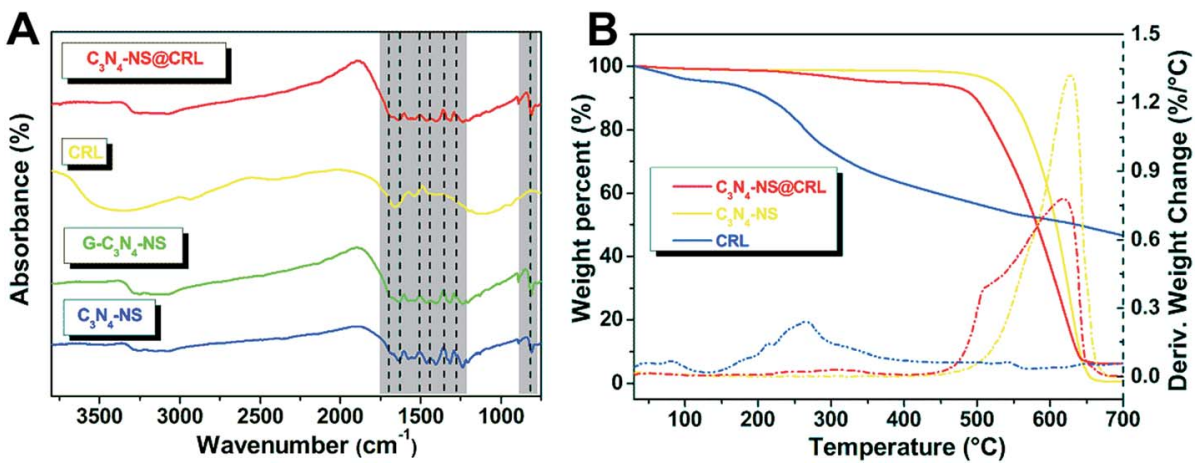

Fig. 3 FT-IR spectra (A) of $\mathrm{C}_{3} \mathrm{~N}_{4}-\mathrm{NS} @ \mathrm{CRL}, \mathrm{CRL}, \mathrm{G}-\mathrm{C}_{3} \mathrm{~N}_{4}-\mathrm{NS}$ and $\mathrm{C}_{3} \mathrm{~N}_{4}-\mathrm{NS}$; (B) TGA analysis of $\mathrm{C}_{3} \mathrm{~N}_{4}-\mathrm{NS}, \mathrm{C}_{3} \mathrm{~N}_{4}-\mathrm{NS} @ \mathrm{CRL}$ and $\mathrm{CRL}$.

The sharp band of $811 \mathrm{~cm}^{-1}$ represented the out-of-plane bending vibration characteristic of heptazine rings. ${ }^{19}$ Although the characteristic absorption peaks of free CRL were highly overlapped with the absorption peaks of $\mathrm{C}_{3} \mathrm{~N}_{4}$-NS, peaks could also be revealed due to CRL and $\mathrm{C}_{3} \mathrm{~N}_{4}-\mathrm{NS}$ in the curve of $\mathrm{C}_{3} \mathrm{~N}_{4}-$ NS@CRL. These results suggest that the whole immobilization process could make sure that the basic structure of carbon nitride nanosheets was intact. In addition, we determined the free $\mathrm{NH}_{2}$ content of $\mathrm{C}_{3} \mathrm{~N}_{4}$-NS via a fluorescamine method and the average value was $1.7 \mathrm{nmol}$ free $\mathrm{NH}_{2}$ groups per $1 \mathrm{mg} \mathrm{C}_{3} \mathrm{~N}_{4}$ NS (Fig. S2†).

The thermal behaviour of $\mathrm{C}_{3} \mathrm{~N}_{4}$-NS, CRL and $\mathrm{C}_{3} \mathrm{~N}_{4}$-NS@CRL was studied by TGA analysis in a nitrogen atmosphere. In Fig. 3B, a sharp decrease in the $\mathrm{C}_{3} \mathrm{~N}_{4}$-NS weight occurred around $600{ }^{\circ} \mathrm{C},{ }^{10}$ which could be attributed to the pyrolysis and decomposition of the $\mathrm{C}_{3} \mathrm{~N}_{4}$-NS polymer fragments. In addition, the TGA curve of CRL showed two major weight loss steps at $80^{\circ} \mathrm{C}$ and $260^{\circ} \mathrm{C}$. The weight loss onset around $80^{\circ} \mathrm{C}$ indicated the evaporation of absorbed water, while the decomposition at $260{ }^{\circ} \mathrm{C}$ could be accredited to denaturation of the CRL structure, ${ }^{9}$ compared with the TGA curve of free CRL. It is worth noting that both $\mathrm{C}_{3} \mathrm{~N}_{4}$-NS and $\mathrm{C}_{3} \mathrm{~N}_{4}$-NS@CRL showed no obvious weight loss (less than $4 \%$ ) from $80{ }^{\circ} \mathrm{C}$ to $300{ }^{\circ} \mathrm{C}$, which could prove the enhanced thermostability of $\mathrm{C}_{3} \mathrm{~N}_{4}$-NS@CRL when CRL was immobilized on the $\mathrm{C}_{3} \mathrm{~N}_{4}$-NS.

\subsection{Assay of biocatalyst activity}

To investigate the application of $\mathrm{C}_{3} \mathrm{~N}_{4}$-NS in the area of biocatalysis, we utilized it to immobilize Candida rugosa lipase (CRL) by covalent binding coupled with glutaraldehyde and evaluated the enzyme activity depending on the hydrolysis of $p$ nitrophenylpalmitate ( $p$-NPP). Due to the multipoint interactions between lipase, glutaraldehyde and tri-s-triazine rings on the surface of $\mathrm{C}_{3} \mathrm{~N}_{4}$-NS, we speculate that those interactions may promote exposure to the catalytic domain of lipase molecules through conformational changes of the open lid domain, thus partly enhancing the enzymatic activity of the hydrolysis of substrate molecules at active sites.

3.2.1. Effect of the lipase concentration. The initial concentration of the free CRL solution employed for immobilization is an important factor in the immobilization process. It affects not only the adsorption amount of the lipase on carriers, but also the activity of immobilized CRL. Fig. 4 shows the effect of lipase concentration on the protein loading amount (Fig. 4A) and the related activity of immobilized lipase and free lipase (Fig. 4B). Taking both aspects into consideration, the lipase concentration was selected as $15 \mathrm{mg} \mathrm{mL}{ }^{-1}$ in the subsequent enzyme immobilization experiments. The results indicated that the lipase loading amount of $\mathrm{C}_{3} \mathrm{~N}_{4}$-NS@CRL was $44.76 \mathrm{mg} \mathrm{g}^{-1}$ of carriers, which could be attributed to the high surface area of the carrier.

3.2.2. Effect of $\mathrm{pH}$ and temperature on the activities of free and immobilized lipase. The $\mathrm{pH}$ and temperature seriously affected the relative activities of free CRL and immobilized CRL when hydrolyzing $p$-nitrophenylpalmitate ( $p$-NPP). ${ }^{9}$ Compared to the free CRL (pH 5.0), the optimum pH of $\mathrm{C}_{3} \mathrm{~N}_{4}$-NS@CRL ( $\mathrm{pH}$ 6.0) shifted toward the basic region, and due to the proton micro-environment, was influenced by the $-\mathrm{NH}_{2}$ groups on the carriers when the free CRL directly accessed the substrate in the soluble form during the reaction. ${ }^{20}$ Meanwhile, the enzyme activity of $\mathrm{C}_{3} \mathrm{~N}_{4}$-NS@CRL showed better performance when the $\mathrm{pH}$ was changed from 4.0 to 8.0, which demonstrated an improved stability in comparison to the free form and showed that the integrity of CRL was preserved over a wider $\mathrm{pH}$ range by immobilization on the obtained $\mathrm{C}_{3} \mathrm{~N}_{4}$-NS (Fig. 5A). In contrast, although the reported immobilized lipase based on mesoporous carbon nitride (CRL@CN-T-600) exhibited optimal enzyme activity at $\mathrm{pH} 5, \mathrm{C}_{3} \mathrm{~N}_{4}$-NS@CRL could be operated under more moderate reaction conditions.

As shown in Fig. 5B, $\mathrm{C}_{3} \mathrm{~N}_{4}$-NS@CRL exhibited better relative enzyme activity in the range from $30{ }^{\circ} \mathrm{C}$ to $50{ }^{\circ} \mathrm{C}(57 \%$ of the initial activity at $50^{\circ} \mathrm{C}$ ). Due to denaturation, the relative activity of the free CRL decreased rapidly when there was an increase in temperature $\left(10 \%\right.$ of the initial activity at $\left.60^{\circ} \mathrm{C}\right)$. In contrast, the $\mathrm{C}_{3} \mathrm{~N}_{4}$-NS@CRL was more heat-resistant than the free CRL at higher temperatures. This may be explained by the formation of chemical bonds during the cross-linking reaction which could effectively restrict the conformation distortion or damage during periods of elevated temperature.

3.2.3. Thermal stability of the free and immobilized lipase. Fig. 5C exhibits the thermal stabilities of $\mathrm{C}_{3} \mathrm{~N}_{4}$-NS@CRL and free CRL. Obviously, the free and immobilized CRL demonstrated similar variation curves between reaction time and 

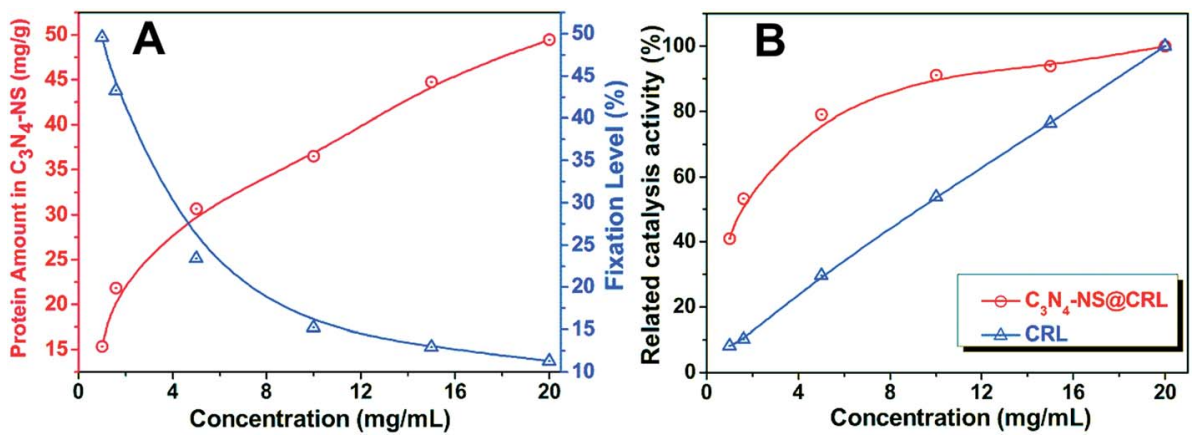

Fig. 4 (A) Effect of the initial protein concentration on the protein amount in $\mathrm{C}_{3} \mathrm{~N}_{4}-\mathrm{NS}(\mathrm{C} C \mathrm{RL}$ and the fixation level; (B) effect of the enzyme concentration on catalysis activity curves of $\mathrm{CRL}$ and $\mathrm{C}_{3} \mathrm{~N}_{4}-\mathrm{NS} @ \mathrm{CRL}$.

relative enzyme activity. The residual relative enzyme activities of $\mathrm{C}_{3} \mathrm{~N}_{4}$-NS@CRL and free CRL gradually declined from 0 to $60 \mathrm{~min}$ at $50{ }^{\circ} \mathrm{C}$, and obtained steady values along with an extended reaction time. After an incubation process lasting for $60 \mathrm{~min}$, the free CRL lost $76 \%$ of its catalytic activity, while $\mathrm{C}_{3} \mathrm{~N}_{4}$ NS@CRL exhibited a remarkable 67\% activity retention under the same conditions. Hence, the thermal stability of $\mathrm{C}_{3} \mathrm{~N}_{4}$ NS@CRL was ameliorated compared with the free lipase, which was probably due to the covalent bonds between lipase molecules and glutaraldehyde, which could enhance the rigidity of Candida rugosa lipase, protect CRL from unfolding and prevent its denaturation at higher temperatures. Besides, the $\mathrm{C}_{3} \mathrm{~N}_{4}{ }^{-}$ NS@CRL exhibited better organic solvent tolerance in nonpolar hydrophobic solvents (hexanol, $n$-hexane, butanol, acetone and
EtOAc) than polar hydrophilic solvents (chloroform, ethanol, DMF, dimethyl sulfoxide (DMSO), methanol and acetic acid), which may be ascribed to the same reason (Fig. S1†).

Under the optimal conditions, the kinetic parameters of the free CRL and $\mathrm{C}_{3} \mathrm{~N}_{4}$-NS@CRL were tested and are listed in Table S1†. The $K_{\mathrm{m}}$ value of the $\mathrm{C}_{3} \mathrm{~N}_{4}$-NS@CRL was 84 times higher than that of the free CRL, indicating that the substrate's affinity capacity for the $\mathrm{C}_{3} \mathrm{~N}_{4}$-NS@CRL was stronger compared to the free CRL. In addition, the specific activity was defined as the initial reaction rate divided by the amount of protein. Based on the $V_{\mathrm{m}}$ values of free $\mathrm{CRL}$ and $\mathrm{C}_{3} \mathrm{~N}_{4}$-NS@CRL, the specific activities were $0.37 \mathrm{U} \mathrm{mg}^{-1}$ and $141.7 \mathrm{U} \mathrm{mg}^{-1}$.

3.2.4. Reusability of the immobilized lipase. For practical applications, reusing enzymes provides a number of cost
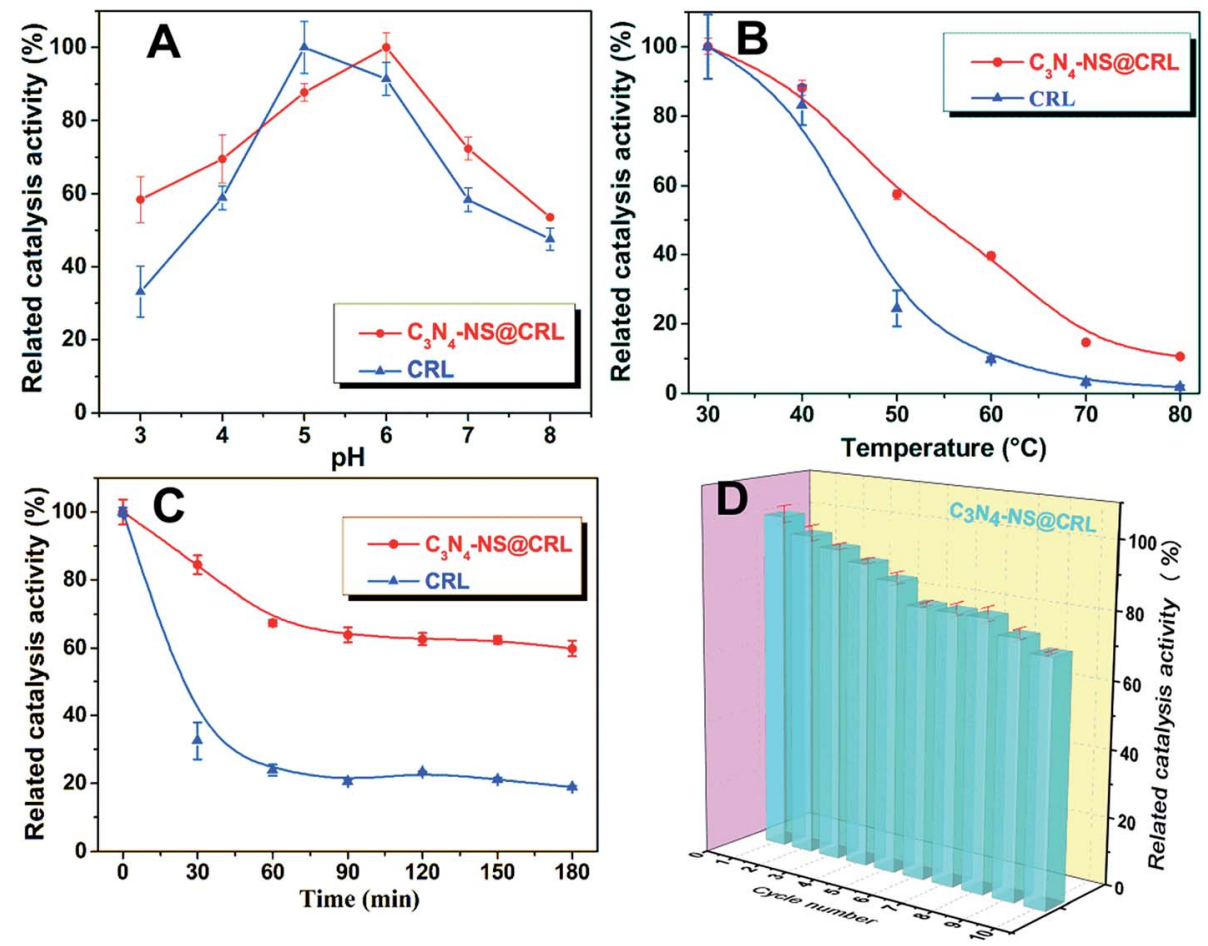

Fig. 5 The pH activity curves (A), temperature activity curves (B) and thermal stability curves (C) for free and immobilized lipase. (D) Reusability assay of immobilized lipase. The activity under optimal conditions was taken as the control (100\%) for the determination of the remaining percentage activity. 
advantages which are an essential prerequisite for establishing an economically viable enzyme-catalyzed process. In this paper, the recyclability of the $\mathrm{C}_{3} \mathrm{~N}_{4}$-NS@CRL was evaluated in consecutive batches of the hydrolysis of $p$-nitrophenylpalmitate ( $p$-NPP) carried out under identical reaction conditions as described previously. Because of the $\mathrm{C}_{3} \mathrm{~N}_{4}-\mathrm{NS}$ of immobilized lipase, the biocatalyst was easily separated and washed by centrifugation during the intervals. The enzyme activity of $\mathrm{C}_{3} \mathrm{~N}_{4}$ NS@CRL after 4 runs decreased by less than 10\%, which was similar to the reported immobilized lipase based on mesoporous carbon nitride (CRL@CN-T-600). Meanwhile, it was found that the $\mathrm{C}_{3} \mathrm{~N}_{4}$-NS@CRL retained $72 \%$ of its initial activity after 10 consecutive operations (Fig. 5D). The gradual but slight decrease in enzyme activity could be due to loss of enzyme activity during separation and washing steps after each use. Thus, the excellent reusability of $\mathrm{C}_{3} \mathrm{~N}_{4}$-NS@CRL provided an excellent long-term catalytic stability.

\section{Conclusion}

In summary, we designed and constructed a novel anchored material for an immobilized enzyme. Benefiting from its expanded surface area, increased number of active sites and 2D nanostructure, $\mathrm{C}_{3} \mathrm{~N}_{4}$-NS was demonstrated to be an excellent carrier for the immobilization of Candida rugosa lipase. Experimental results indicated that the obtained immobilized lipase $\left(\mathrm{C}_{3} \mathrm{~N}_{4}\right.$-NS@CRL) demonstrated enhanced enzyme-loading (44.76 $\mathrm{mg} \mathrm{g}^{-1}$ ), pH-flexibility ( $\mathrm{pH} 4.0-8.0$ ), thermostability (after $180 \mathrm{~min}$ at $50{ }^{\circ} \mathrm{C}, 67 \%$ of the initial activity remained) and recyclability (after 10 runs, $72 \%$ of the initial activity remained). To the best of our knowledge, it is the first time that the application of carbon nitride nanosheets to the area of immobilized enzymes has been reported. Finally, our present strategy could be generalized to construct other immobilized enzyme combinations through the use of other templates.

\section{Conflicts of interest}

There are no conflicts to declare.

\section{Acknowledgements}

We are grateful to the National Science Foundation of China (no. 31501423, 31701560 and 31671820), the Young Elite Scientists Sponsorship Program by CAST (2017QNRC001), the Director Fund of Oil Crops Research Institute of CAAS (no. 1610172015006) and the Agricultural Science and Technology
Innovation Project of Chinese Academy of Agricultural Sciences (CAAS-ASTIP-2013-OCRI) for financial support.

\section{References}

1 S. A. Ansari and Q. Husain, Biotechnol. Adv., 2012, 30, 512523.

2 S. Benjamin and A. A. Pandey, Yeast, 1998, 14, 1069-1087.

3 R. Sharma, Y. Chisti and U. C. Banerjeea, Biotechnol. Adv., 2001, 19, 627-662.

4 I. V. Pavlidis, T. Tsoufis, A. Enotiadis, D. Gournis and H. Stamatis, Adv. Eng. Mater., 2010, 12, 179-183.

5 J. F. Shi, X. L. Wang, S. H. Zhang, L. Tang and Z. Y. Jiang, J. Mater. Chem. B, 2016, 4, 2654-2661.

6 B. Luo, G. Liu and L. Z. Wang, Nanoscale, 2016, 8, 6904-6920.

7 I. V. Pavlidis, M. Patila, U. T. Bornscheuer, D. Gournis and H. Stamatis, Trends Biotechnol., 2014, 32, 312-320.

8 S. Hermanova, M. Zarevucka, D. Bousa, M. Pumera and Z. Sofer, Nanoscale, 2015, 7, 5852-5858.

9 S. Zhang, J. Shi, Q. C. Deng, M. M. Zheng, C. Y. Wan, C. Zheng, Y. Li and F. H. Huang, Molecules, 2017, 22, 12051220.

10 Y. Wang, X. C. Wang and M. Antonietti, Angew. Chem., Int. Ed., 2012, 51, 68-89.

11 A. W. Wang, C. D. Wang, L. Fu, W. Wong-Ng and Y. C. Lan, Nano-Micro Lett., 2017, 9, 47-68.

12 C. L. Tan, X. H. Cao, X. J. Wu, Q. Y. He, J. Yang, X. Zhang, J. Z. Chen, W. Zhao, S. K. Han, G. H. Nam, M. Sindoro and H. Zhang, Chem. Rev., 2017, 117, 6225-6331.

13 X. D. Zhang, X. Xie, H. Wang, J. J. Zhang, B. C. Pan and Y. Xie, J. Am. Chem. Soc., 2013, 135, 18-21.

14 L. C. Chen and J. B. Song, Adv. Funct. Mater., 2017, 27, 1702695.

15 W. Z. Shen, L. W. Ren, H. Zhou, S. C. Zhang and W. B. Fan, J. Mater. Chem., 2011, 21, 3890.

16 P. Niu, L. L. Zhang, G. Liu and H. M. Cheng, Adv. Funct. Mater., 2012, 22, 4763-4770.

17 Y. L. Fan, F. Su, K. Li, C. X. Ke and Y. J. Yan, Sci. Rep., 2017, 7, 45643.

18 M. M. Bradford, Anal. Biochem., 1976, 72, 248-254.

19 H. Xu, J. Yan, X. J. She, L. Xu, J. X. Xia, Y. Xu, Y. G. Song, L. Y. Huang and H. M. Li, Nanoscale, 2014, 6, 1406-1415.

20 T. L. d. Albuquerque, N. Rueda, J. C. S. dos Santos, O. Barbosa, C. Ortiz, B. Binay, E. Özdemir, L. R. B. Gonçalves and R. Fernandez-Lafuente, Process Biochem., 2016, 51, 865-874. 